\title{
COMPARATIVE PERFORMANCE OF SACCHARUM OFFICINARUM(SUGAR CANE) BAGASSE AND PARKIA BIGLOBOSA (LOCUST BEAN) IN WASTEWATER TREATMENT
}

\author{
A. Adamu ${ }^{1, *}$ and M. S. Ahmadu ${ }^{2}$

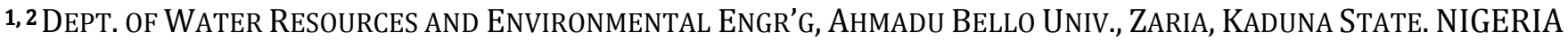 \\ Email addresses:1 adamualiyu@abu.edu.ng, 2 aadandaje@gmail.com
}

\begin{abstract}
The application of agricultural by-products for the removal of contaminants in water and wastewater is receiving significant attention as their applications reduce their level of the agricultural by-products in the environment there by reducing pollution. Activated carbons were formed from the saccharum officinarum (sugarcane) bagasse and parkia biglobosa (locust bean) pods and their effectiveness in the treatment of domestic wastewater were compared. The activated carbons were obtained from carbonised sugarcane bagasse and locust beanpod at a temperature of $350-500^{\circ} \mathrm{C}$, followed by the modification with phosphoric acid for 12-18 hours. The result revealed that the parkia biglobosa recorded higher removal efficiencies of: Turbidity, Biochemical Oxygen Demand (BOD), Chemical Oxygen Demand (COD) and nitrate than the saccharum officinarum. The parkia biglobosa recorded BOD removal efficiencies of: $77.19,77.81,78.13,87.50,90.63$ and $93.75 \%$ at the dosages of: $0.25,0.5,1.5,2.5,3.75$ and $5.00 \mathrm{~g} / 500 \mathrm{ml}$, respectively; while the saccharum officinarum recorded removal efficiencies of: 15.63, 25.00, 34.38, 43.44, 46.88 and $65.00 \%$ at the same dosages, implying that the parkia biglobosa was more effective than saccharum officinarum. In terms of turbidity, the saccharum officinarum recorded removal efficiencies of: 5.44, $17.86,31.90,34.29,46.51$ and $57.02 \%$, respectively at the dosages of: $0.25,0.5,1.5,2.5,3.75$ and $5.00 \mathrm{~g} / 500 \mathrm{ml}$; while parkia biglobosa recorded removal efficiencies of: 14.99, 25.50, 37.63, 43.84, 56.07 and 68.39\%.The study also revealed that the higher the dosages, the higher the removal efficiencies of the organic and inorganic pollutants. It was recommended that removal of heavy metals using the parkia biglobosa and saccharum officinarum should be studied to ascertain their effectiveness in such dimension.
\end{abstract}

Keywords: wastewater, activated carbons, saccharum officinarum, parkia biglobosa and removal efficiency

\section{INTRODUCTION}

Wastewater contains about $99.9 \%$ of water by mass, while the remaining $0.1 \%$ is solids. The contaminants in wastewater include: suspended solids, biodegradable organic compounds, inorganic solids, nutrients, heavy metals as well as pathogens. Wastewater is usually treated in order to be discharged safely, without any health implication or water pollution [1].

Saccharum officinarum (sugarcane) bagasse is the solid remains obtained after the extraction of juice from the sugarcane $[2,3,4]$. Sugarcane bagasse is composed of: $43.6 \%$ by mass cellulose, $33.8 \%$ hemicellulose, $18.1 \%$ lignin, $2.3 \%$ ash and $0.8 \%$ wax on a dry weight basis $[3,5]$. The lignocelluloses (cellulose, hemi-cellulose and lignin) can be used to produce ethanol which is an alternative source of energy [6]. The saccharum officinarum bagasse is inexpensive and readily available as agricultural by-product with significant carbon content $[6,7,8]$. Moreso, a pyrolysed sugarcane bagasse has elemental composition of: $22.36 \%$ carbon, $30.69 \%$ nitrogen and $30.52 \%$ oxygen [9]. The chemical composition of raw saccharum officinarum bagasse depends upon multiple factors such as: crop variety, climate condition, location, mode of growth and chemical composition of the soil [4].

The parkia biglobosa, commonly known as the African locust bean [10], is a perennial tree of legume, belonging to the family of leguminosae $[10,11,12]$. The seeds of the plant are enclosed in a yellowish, mealy, sweet tasting edible pulp. The leaf extract 
contains cardiac, saponin glycosides and phenolic content [10]. The fruit pulp and seeds are rich in protein and lactose constituting vital form of energy $[10,13]$. The roots, barks, leaves, stem, flowers, fruits and seed of a parkia biglobosa are all medicinal [14]. The parkia biglobosa tree reaches $7-20 \mathrm{~m}$ in height and the crown is large and wide spreading with low branches on a stout bole [11].

The parkia biglobosa seeds number 5 - 20 per pod. The seeds are brown, oval, and smooth with a length of $0.9-1.5 \mathrm{~cm}$ each, $0.8-1.1 \mathrm{~cm}$ width and a weight of $0.25 \mathrm{~g}$ [11]. However, the plant has the capacity to resist drought situation due to its deep tap root system [15].

The application of agricultural by-products for the treatment of water and wastewater is currently receiving great attention. The mechanism through which the treatment occurs is referred to as adsorption which is a surface phenomenon $[16,17]$. The adsorption could be physical or chemical [18]. The applications of saccharum officinarum bagasse and parkia biglobosa in wastewater treatment involve their modifications to produce activated carbon. The effectiveness of the activated carbon depends upon the production process and modification [19]. The aim of this research is to compare the effectiveness of activated carbons produced from parkia biglobosa pod and saccharum officinarum bagasse in wastewater treatment based on the removal of organic pollutants.

\section{MATERIALS AND METHODS}

\subsection{Materials}

The materials used in this research are categorized as: glassware, equipment or apparatus and reagents:

\subsubsection{Glassware}

The glassware used were: test tubes, petri-dish, desiccators, burette, pipette, conical flask, measuring cylinder, Biochemical Oxygen Demand (BOD) bottle, beaker, glass beads and reflux apparatus/flask.

\subsubsection{Equipment/apparatus}

pH meter (HI 83200), weighing balance (P160N), retort stand, sterilizing machine, Turbid meter (HACH $2100 \mathrm{~N}$ ), water bath, funnel, filter paper, crucible, sag, furnaces, griffen oven, 20 litregaloon, hand glove, magnetic stirrer, multi-parameter photometer, spatula and forcept.

\subsubsection{Reagents}

Molybdate reagent, methylated spirit, manganous sulphate, ferrous ammonium sulphate, phenolphthalein indicator, methyl ferroin indicator, sodium thiosulphate, concentrated phosphoric acid, concentrated tetraoxosulphate (VI), magnesium sulphate, alkali-iodide/azide,starch solution, sodium thiosulphate, mercury sulphate, buffer solution 4, 6 and 9, distilled water, starch solution, potassium choromate and silver sulphate all of analytical grade.

\subsection{Methods}

\subsubsection{Preparation of Saccharum officinarum Bagasse and Parkia biglobosa Activated Carbons}

The saccharum officinarum bagasse was collected from Makarfi Local Government Area of Kaduna state; while the parkia biglobosa was obtained from Ahmadu Bello University, Zaria -Nigeria; opposite the University reservoir. They were washed separately with distilled water to remove dirt and surface impurities, and then oven dried at $100^{\circ} \mathrm{C}$ for 24 hours $[20,21]$. They were then cut into smaller pieces and placed in a miller which consists of a series of rollers that crush them. They were then placed in a crucible and charred in a furnace at $350^{\circ} \mathrm{C}-500^{\circ} \mathrm{C}$. The furnace was allowed to cool down for 24hours before the charred were removed and sieved to obtain $5-50 \mu \mathrm{m}$ grain size for material that passes through sieve number 200. The sieved materials were then soaked in phosphoric acid for 12-18hours to become activated carbons. They were then washed with distilled water, spread on tray at room temperature to be drained. The product was then dried at temperature at $105^{\circ} \mathrm{C}$ for 3 hours and kept in desiccators to cool down.

\subsubsection{Sampling}

Wastewater was collected from maturation pond effluent of Ahmadu Bello University waste treatment plant in a 20 litres gallon. It was then taken to the Environmental Health Laboratory, Department of Water Resources and Environmental Engineering, Ahmadu Bello University, Zaria for the physicochemical analysis using standard methods for water and wastewater quality assessment. The parameters analysed are: turbidity, total solids, suspended solids, pH, Biochemical Oxygen Demand (BOD), Chemical Oxygen Demand (COD), nitrate and phosphate. 


\subsubsection{Batch Adsorption Experiment}

The batch adsorption was carried out by measuring: $0.25,0.5,1.5,2.5,3.75$, and $5.0 \mathrm{~g}$ of the saccharum officinarum bagasse and parkia biglobosa pod activated carbons each in a $500 \mathrm{ml}$ of waste water. The mixture of activated carbons and the wastewater sample were stirred at $100 \mathrm{rpm}$ high speed for 5 minute and 10rpm low speed for 15 minute using magnetic stirrer. The samples were then removed from the magnetic stirrer and the flocs were allowed to settle down.

\section{RESULTS AND DISCUSSION}

The results obtained in this study were presented in Tables $1-8$, showing the performances of the saccharum officinarum bagasse and parkia biglobosa for the removal of both physical and chemical pollutants in the wastewater. Table 1 revealed the removal of turbidity of the wastewater at an initial turbidity value of 10.47 NTU. The saccharum officinarum bagasse recorded removal efficiencies of: $5.44,17.86,31.90,34.29,46.51$ and $57.02 \%$, respectively at the dosages of $0.25,0.5,1.5,2.5,3.75$ and $5.00 \mathrm{~g} / 500 \mathrm{ml}$. This implied that the highest removal efficiency of $57.02 \%$ was recorded at the dosage of $5.00 \mathrm{~g} / 500 \mathrm{ml}$, while the lowest removal efficiency was recorded at the dosage of $0.25 \mathrm{~g} / 500 \mathrm{ml}$. The result implied that the removal efficiencies of the turbidity in the wastewater increases with the increase in the dosage of the adsorbent. On the other hand, the parkia biglobosa recorded removal efficiencies of the turbidity of: $14.99,25.50,37.63$, $43.84,56.07$ and $68.39 \%$, respectively at the dosages of $0.25,0.5,1.5,2.5,3.75$ and $5.00 \mathrm{~g} / 500 \mathrm{ml}$. The highest removal efficiency of $68.38 \%$ occurred at the dosage of $5.00 \mathrm{~g} / 500 \mathrm{ml}$, while the lowest removal efficiency of $14.99 \%$ occurred at the dosage of 0.25 $\mathrm{g} / 500 \mathrm{ml}$. The parkia biglobosa recorded higher turbidity removal efficiency than the saccharum officinarum bagasse at all the adsorbent dosages. Moreover, modified cassava species (manihot palmate and manihotaipi) can also be used to remove turbidity in water and wastewater [22].

Table 1: Turbidity values(NTU)

\begin{tabular}{ccccc}
\hline \multirow{2}{*}{ Dose $(\mathrm{g} / 500 \mathrm{ml})$} & \multicolumn{3}{c}{ Comparison in turbidity } & Removal efficiency (\%) \\
\cline { 2 - 5 } & Saccharum officinarum (NTU) & Parkia biglobosa(NTU) & saccharum officinarum & Parkia biglobosa Pod \\
\hline 0.00 & 10.47 & 10.47 & 0.00 & 0.00 \\
0.25 & 9.90 & 8.90 & 5.44 & 14.99 \\
0.50 & 8.60 & 7.80 & 17.86 & 25.50 \\
1.50 & 7.13 & 6.53 & 31.90 & 37.63 \\
2.50 & 6.88 & 5.88 & 34.29 & 43.84 \\
3.75 & 5.60 & 4.60 & 46.51 & 56.07 \\
5.00 & 4.50 & 3.31 & 57.02 & 68.39 \\
\hline
\end{tabular}

Table 2: Suspended solids values ( $\mathrm{mg} / \mathrm{I})$

\begin{tabular}{|c|c|c|c|c|}
\hline \multirow{2}{*}{$\begin{array}{c}\text { Dose } \\
(\mathrm{g} / 500 \mathrm{ml})\end{array}$} & \multicolumn{2}{|c|}{ Comparison in concentration of suspended solids } & \multicolumn{2}{|l|}{ Removal efficiency (\%) } \\
\hline & Saccharum officinarum $(\mathrm{mg} / \mathrm{l})$ & Parkia Biglobosa (mg/l) & saccharum officinarum & Parkia biglobosa \\
\hline 0.00 & 8.50 & 8.50 & 0.00 & 0.00 \\
\hline 0.25 & 0.02 & 0.02 & 94.12 & 94.12 \\
\hline 0.50 & 0.02 & 0.02 & 94.12 & 94.12 \\
\hline 1.50 & 0.01 & 0.01 & 99.88 & 99.88 \\
\hline 2.50 & 0.01 & 0.01 & 99.88 & 99.88 \\
\hline 3.75 & 0.01 & 0.01 & 99.88 & 99.88 \\
\hline 5.00 & 0.01 & 0.01 & 99.88 & 99.88 \\
\hline \multicolumn{5}{|c|}{ Table 3: Total solids values $(\mathrm{mg} / \mathrm{l})$} \\
\hline \multirow{2}{*}{ Dose $(\mathrm{g} / 500 \mathrm{ml})$} & \multicolumn{2}{|c|}{ Comparison in concentration of total solids } & \multicolumn{2}{|c|}{ Percentage Removal (\%) } \\
\hline & saccharum officinarum $(\mathrm{mg} / \mathrm{l})$ & Parkia biglobosa $(\mathrm{mg} / \mathrm{l})$ & saccharum officinarum & Parkia biglobosa \\
\hline 0.00 & 9.70 & 9.70 & 0.00 & 0.00 \\
\hline 0.25 & 0.016 & 0.030 & 99.84 & 99.69 \\
\hline 0.50 & 0.016 & 0.030 & 99.84 & 99.69 \\
\hline 1.50 & 0.015 & 0.026 & 99.85 & 99.73 \\
\hline 2.50 & 0.014 & 0.025 & 99.86 & 99.74 \\
\hline 3.75 & 0.013 & 0.023 & 99.87 & 99.76 \\
\hline 5.00 & 0.011 & 0.021 & 99.89 & 99.78 \\
\hline
\end{tabular}


The suspended solids removal was as shown in Table 2. The initial concentration of the suspended solids in the wastewater was $8.50 \mathrm{mg} / \mathrm{l}$. The saccharum officinarum bagasse and parkia biglobosa had removal efficiencies of: 94.12, 94.12, 99.88, 99.88, 99.88 and $99.88 \%$, respectively at the dosages of $0.25,0.5,1.5$, 2.5, 3.75 and $5.00 \mathrm{~g} / 500 \mathrm{ml}$. This implied that the same removal efficiencies were obtained for both the saccharum officinarum bagasse and parkia biglobosa at all the dosages considered. The result also revealed that higher dosages of the adsorbent are accompanied with higher removal efficiencies [23] and $1.5 \mathrm{~g} / 500 \mathrm{ml}$ dosage recorded the highest removal efficiency.

The result of the total solids was as shown in Table 3. The initial concentration of the total solids in the wastewater was $9.70 \mathrm{mg} / \mathrm{l}$. The saccharum officinarum bagasse recorded removal efficiencies of: 99.84, 99.84, $99.85,99.86,99.87$ and $99.89 \%$, respectively at the dosages of $0.25,0.5,1.5,2.5,3.75$ and $5.00 \mathrm{~g} / 500 \mathrm{ml}$. On the other hand, the parkia biglobosa recorded removal efficiencies of: 99.69, 99.69, 99.73, 99.74, 99.76 and $99.78 \%$, respectively at the dosages of 0.25 , $0.5,1.5,2.5,3.75$ and $5.00 \mathrm{~g} / 500 \mathrm{ml}$. The result implied that higher dosages of the adsorbent are accompanied by higher removal efficiency of the adsorbent [23] as shown in the Table 3.

Table 4 contained the $\mathrm{pH}$ values of the waste water before and after the application of various dosages of the adsorbents. The initial $\mathrm{pH}$ of the waste water was
6.13, but it was reduced to $2.55,2.64,2.78,3.05,3.02$ and 4.15 , respectively at the dosages of $0.25,0.5,1.5$, 2.5, 3.75 and $5.00 \mathrm{~g} / 500 \mathrm{ml}$ for the activated saccharum officinarum bagasse. On the other hand, the application of the $0.25,0.5,1.5,2.5,3.75$ and 5.00 $\mathrm{g} / 500 \mathrm{ml}$ of the adsorbent dosage, respectively reduced the $\mathrm{pH}$ to $2.10,3.08,4.12,2.03,2.05$ and 3.15 for the parkia biglobosa. This implied that the application of both the adsorbents at all the dosages dropped the $\mathrm{pH}$ of the waste water making it to be more acidic. This signified that the waste water will require $\mathrm{pH}$ adjuster in order to neutralize the waste water.

The result of the BOD was as shown in Table 5. The initial concentration of the BOD in the waste water was $3.2 \mathrm{mg} / \mathrm{l}$. The applications of: $0.25,0.5,1.5,2.5$, 3.75 and $5.00 \mathrm{~g} / 500 \mathrm{ml}$, respectively of the activated saccharum officinarum bagasse dosages reduced the BOD to 2.70, 2.40, 2.10, 1.81, 1.70 and $1.20 \mathrm{mg} / \mathrm{l}$. This corresponds to the BOD removal efficiencies of: 15.63, $25.00,34.38,43.44,46.88$ and $65.00 \%$. It was discovered that the removal efficiencies of the BOD increases with the increase in the adsorbent dosages as shown in the Table 5 as observed by [22]. The increase in the adsorbent dosage causes the number of sites available for solute-solvent interaction to increase thereby improving the removal efficiency $[23,24]$.

Table 4: $p H$ values

\begin{tabular}{ccccc}
\hline \multirow{2}{*}{ Dose $(\mathrm{g} / 500 \mathrm{ml})$} & \multicolumn{2}{c}{ Comparison(pH values) } & \multicolumn{2}{c}{ Removal efficiency (\%) } \\
\cline { 2 - 5 } & saccharum officinarum & Parkia biglobosa & saccharum officinarum & Parkia biglobosa \\
\hline 0.00 & 6.13 & 6.13 & 0.00 & 0.00 \\
0.25 & 2.55 & 2.10 & 58.40 & 65.74 \\
0.50 & 2.64 & 3.08 & 56.90 & 49.76 \\
1.50 & 2.78 & 4.12 & 54.50 & 32.79 \\
2.50 & 3.05 & 2.03 & 50.25 & 66.89 \\
3.75 & 3.02 & 2.05 & 32.30 & 66.56 \\
5.00 & 4.15 & 3.15 & 32.30 & 48.61 \\
\hline
\end{tabular}

Table 5: Biochemical Oxygen Demand (BOD) values (mg/l)

\begin{tabular}{|c|c|c|c|c|}
\hline \multirow{3}{*}{ Dose $(\mathrm{g} / 500 \mathrm{ml})$} & \multicolumn{2}{|c|}{ Comparison in concentration of BOD } & \multicolumn{2}{|c|}{ Removal efficiency (\%) } \\
\hline & saccharum officinarum & $\begin{array}{c}\text { Parkia } \\
\text { biglobosa }\end{array}$ & \multirow[t]{2}{*}{ saccharum officinarum } & \multirow{2}{*}{$\begin{array}{c}\text { Parkia } \\
\text { biglobosa }\end{array}$} \\
\hline & $\mathrm{BOD}(\mathrm{mg} / \mathrm{l})$ & $\mathrm{BOD}(\mathrm{mg} / \mathrm{l})$ & & \\
\hline 0.00 & 3.20 & 3.20 & 0.00 & 0.00 \\
\hline 0.25 & 2.70 & 0.73 & 15.63 & 77.19 \\
\hline 0.50 & 2.40 & 0.71 & 25.00 & 77.81 \\
\hline 1.50 & 2.10 & 0.70 & 34.38 & 78.13 \\
\hline 2.50 & 1.81 & 0.40 & 43.44 & 87.50 \\
\hline 3.75 & 1.70 & 0.30 & 46.88 & 90.63 \\
\hline 5.00 & 1.20 & 0.20 & 65.00 & 93.75 \\
\hline
\end{tabular}


Table 6: Chemical Oxygen Demand (COD) values ( $\mathrm{mg} / \mathrm{l}$ )

\begin{tabular}{ccccc}
\hline \multirow{2}{*}{ Dose $(\mathrm{g} / 500 \mathrm{ml})$} & \multicolumn{2}{c}{ Comparison in concentration of COD } & \multicolumn{2}{c}{ Removal efficiency (\%) } \\
\cline { 2 - 5 } & \multirow{2}{*}{ saccharum officinarum $(\mathrm{mg} / \mathrm{l})$} & Parkia biglobosa $(\mathrm{mg} / \mathrm{l})$ & Saccharum officinarum & Parkia biglobosa \\
\hline 0.00 & 25.0 & 25.0 & 0.00 & 0.00 \\
0.25 & 17.20 & 8.20 & 31.20 & 67.20 \\
0.50 & 14.70 & 7.70 & 41.20 & 69.20 \\
1.50 & 13.90 & 6.50 & 44.40 & 74.00 \\
2.50 & 11.40 & 6.50 & 54.50 & 74.00 \\
3.75 & 11.12 & 6.30 & 55.52 & 74.80 \\
5.00 & 10.20 & 6.20 & 59.20 & 75.20 \\
\hline
\end{tabular}

Table 7: Nitrate values ( $\mathrm{mg} / \mathrm{l})$

\begin{tabular}{ccccc}
\hline Dose $(\mathrm{g} / 500 \mathrm{ml})$ & \multicolumn{2}{c}{ Comparison in concentration of nitrate } & \multicolumn{2}{c}{ Removal efficiency (\%) } \\
\cline { 2 - 5 } & saccharum officinarum(mg/l) & Parkia biglobosa(mg/l) & saccharum officinarum & Parkia biglobosa \\
\hline 0.00 & 37.0 & 37.0 & 0.00 & 0.00 \\
0.25 & 25.5 & 22.3 & 31.07 & 39.73 \\
0.50 & 13.3 & 16.0 & 64.10 & 56.76 \\
1.50 & 14.2 & 11.9 & 61.62 & 67.84 \\
2.50 & 20.2 & 14.7 & 45.40 & 60.27 \\
3.75 & 12.9 & 13.5 & 65.14 & 63.51 \\
5.00 & 18.8 & 11.1 & 49.20 & 70.0 \\
\hline
\end{tabular}

Table 8: Phosphate values ( $\mathrm{mg} / \mathrm{l})$

\begin{tabular}{ccccc}
\hline Dose $(\mathrm{g} / 500 \mathrm{ml})$ & \multicolumn{3}{c}{ Comparison in concentration of phospate } & Removal efficiency (\%) \\
\cline { 2 - 5 } & saccharum officinarum $(\mathrm{mg} / \mathrm{l})$ & Parkia biglobosa(mg/l) & saccharum officinarum & Parkia Biglobosa Pod \\
\hline 0.00 & 1.13 & 1.13 & 0.00 & 0.00 \\
0.25 & 0.63 & 0.81 & 44.23 & 28.32 \\
0.50 & 0.76 & 0.80 & 32.74 & 29.20 \\
1.50 & 0.71 & 0.79 & 37.17 & 43.09 \\
2.50 & 0.74 & 0.74 & 34.51 & 34.51 \\
3.75 & 0.60 & 0.73 & 46.90 & 48.40 \\
5.00 & 0.55 & 0.54 & 51.33 & 52.21 \\
\hline
\end{tabular}

On the other hand, the activated parkia biglobosa recorded higher removal efficiencies of the BOD than the sugarcane bagasse. It recorded removal efficiencies of: 77.19, 77.81, 78.13, 87.50, 90.63 and $93.75 \%$, respectively at the dosages of $0.25,0.5,1.5$, $2.5,3.75$ and $5.00 \mathrm{~g} / 500 \mathrm{ml}$. This signified that the parkia biglobosais more effective in terms of organic matter removal than saccharum officinarumas the result revealed.

The result of the COD was as shown in Table 6. The initial concentration of the COD in the waste water was $25.0 \mathrm{mg} / \mathrm{l}$. The applications of: $0.25,0.5,1.5,2.5$, 3.75 and $5.00 \mathrm{~g} / 500 \mathrm{ml}$, respectively of the activated saccharum officinarum led to the removal efficiencies of: $31.2,41.2,44.4,54.5,55.52$ and $59.2 \%$ of the COD. It was discovered that the removal efficiencies of the COD increases with the increase in the adsorbent dosages as it was previously discussed earlier. On the other hand, the activated parkia biglobosa recorded higher removal efficiencies of the COD than the activated saccharum officinarum. It recorded removal efficiencies of: $67.2,69.2,74.0,74.0,74.8$ and 75.2\%, respectively at the corresponding dosages of: $0.25,0.5$, $1.5,2.5,3.75$ and $5.00 \mathrm{~g} / 500 \mathrm{ml}$. This signified that the activated parkia biglobosa is more effective in terms of organic matter removal than saccharum officinarum as the result revealed.

Table 7 showed the removal efficiencies of the nitrate in the wastewater. The activated saccharum officinarum recorded removal efficiencies of: 31.07 , $64.10,61.62,45.40,65.14$ and $49.2 \%$, respectively at the corresponding dosages of: $0.25,0.5,1.5,2.5,3.75$ and $5.00 \mathrm{~g} / 500 \mathrm{ml}$. This implied that the activated saccharum officinarum had the lowest removal efficiency of: $31.07 \%$ and highest removal efficiency of $65.14 \%$ at the dosages of $0.25 \mathrm{~g} / 500 \mathrm{ml}$ and 3.75 , respectively. On the other hand, the activated parkia biglobosa recorded removal efficiencies of: 39.73, $56.76,67.84,60.27,63.51$ and $70.0 \%$, respectively at the dosages of: $0.25,0.5,1.5,2.5,3.75$ and 
$5.00 \mathrm{~g} / 500 \mathrm{ml}$. This signified that the activated parkia biglobosa had the lowest removal efficiency of: $39.73 \%$ and highest removal efficiency of: $70.0 \%$ at the dosages of $0.25 \mathrm{~g} / 500 \mathrm{ml}$ and $5.00 \mathrm{~g} / 500 \mathrm{ml}$, respectively. The result also revealed that the performance of the activated parkia biglobosa is more than the activated sugar cane bagasse for nitrate removal.

Table 8 showed the removal of the phosphate for both the activated saccharum officinarum bagasse and parkia biglobosa at an initial phosphate concentration of $1.13 \mathrm{mg} / \mathrm{l}$. The activated saccharum officinarum bagasse recorded removal efficiencies of: 44.23, 32.74, $37.17,34.51,46.90$ and $51.33 \%$, respectively at the dosages of $0.25,0.5,1.5,2.5,3.75$ and $5.00 \mathrm{~g} / 500 \mathrm{ml}$. The result implied that the highest removal efficiency of: $51.33 \%$ was recorded at the dosage of $5.00 \mathrm{~g} / 500 \mathrm{ml}$, while the lowest removal efficiency of: $32.74 \%$ was recorded at the dosage of $0.5 \mathrm{~g} / 500 \mathrm{ml}$. On the other hand, the parkia biglobosa recorded removal efficiencies of: 28.32, 29.20, 43.09, 34.51, 48.40 and $52.21 \%$, respectively at the corresponding dosages of: $0.25,0.5,1.5,2.5,3.75$ and $5.00 \mathrm{~g} / 500 \mathrm{ml}$. The highest removal efficiency of $52.21 \%$ was recorded at the dosage of $5.00 \mathrm{~g} / 500 \mathrm{ml}$, while the lowest removal efficiency of $28.32 \%$ was recorded at the dosage of $0.25 \mathrm{~g} / 500 \mathrm{ml}$.

\section{CONCLUSION}

Based on the experiment carried in this research, it was discovered that both the saccharum officinarum bagasse and parkia biglobosa can be used for the removal of organic and inorganic pollutants in wastewater. The comparative results revealed that the parkiabiglobossa had higher removal effienciencies of the: turbidity, BOD, COD and nitrate removal from the wastewater than the saccharum officinarum bagasse. However, the parkia biglobosa recorded BOD removal efficiencies of: 15.63, 25.00, 34.36, 43.44, 46.88 and $65.00 \%$,respectively at the dosages of $0.25,0.5,1.5$, $2.5,3.75$ and $5.00 \mathrm{~g} / 500 \mathrm{ml}$; while the saccharum officinarum bagasse recorded removal efficiencies of: $77.19,77.81,78.13,87.50,90.63$ and $93.75 \%$ at the same dosages. In terms of turbidity, the saccharum officinarum recorded removal efficiencies of: 5.44, $17.86,31.90,34.29,46.51$ and $57.02 \%$, respectively at the dosages of: $0.25,0.5,1.5,2.5,3.75$ and $5.00 \mathrm{~g} / 500 \mathrm{ml}$; while parkia biglobosa recorded removal efficiencies of: $14.99,25.50,37.63,43.84$, 56.07 and $68.39 \%$.The study also revealed that the higher the dosages, the higher the removal efficiencies of the pollutants. It is recommended that removal of heavy metals using the parkia biglobosa and saccharum officinarum bagasse should be studied to ascertain their effectiveness in such dimension.

\section{REFERENCES}

[1] Templeton, M. R. and Butter, D. "An introduction to wastewater treatment", available on line at www.bookboon.com, 2011

[2] Amores, I., Ballesteros, I.,Manzanares, P., Saez, F., Michelena, G. and Ballesteros, M., "Ethanol production from sugarcane bagasse pretreated by steam explosion", Electronic Journal of Energy and Environment, vol. 1(1), 2013

[3] Lois-Correa, J.,Flores-Velva, A., Orgeta-Grimaldo, D. and Berman-Belgado, J."Experimental evaluation of sugarcane bagasse storage in Bales system", Journal of Applied Research and Technology, vol.8 (3), 2010, pp 365-377.

[4] Chandel, A.K., Silva, S.S., Carvalho, W., and Singh, O. V. "Sugarcane bagasse and leaves: foreseeable biomass of biofuel and bio-products", Journal of Chemical Technology, Society of Chemical Industry, 2011

[5] Ahmed, F. M., Rahman, S.R., Gomes, D. J. "Saccharification of sugarcane bagasse by enzymatic treatment for bioethnol production", Malaysian Journal of Microbiology, vol.8(2), 2012, pp97-103.

[6] Lee, Y. "Oxidation of sugarcane bagasse using a combination of hypochlorite and peroxide", MSc thesis, Graduate Faculty of the Louissiana State University and Agricultural and Mechanical College, 2005

[7] Javed, M.M., Haq, I., Khan, T. S. "Sugarcane bagasse pretreatment: an attempt to enhance the production potential of cellulose by HumicolaInsulens TAS-13", An International Journal of Nigerian Society for Experimental Biology, vol.18(2), 2006, pp 83-88

[8] Pereira, P. H. F. and Voorwald, H. C. J. "Sugarcane bagasse, pulping and bleaching: thermal and chemical characterization", Journal of Bioresources, vol.6 (3), 2011, pp 2471-2482.

[9] Devnarain, P. B., Arnold, D. R., and Davis, S. B." Production of activated carbon from south African sugarcane bagasse,proc South Afican technol Ass, 76,2002

[10] Olabinri, B.M., Adetutu, A., Olaleye, M.T., Oluwafunsho, B. O. and Oyeniyi, O.O. "A study of the antioxidative potentials of acetone and aqueous extracts of parkia biglobosa and tetracarpidiumconophorumstem barks in vitro", An International Journal of Medicine and Medical Sciences, vol.5(8), 2013, pp 368-373

Vol. 34 No. 4, October 2015 
[11] Shao, M. "Parkia biglobosa: changes in resource allocation in Kandiga Ghana", MSc thesis, Michigan Technological University, 2002.

[12] Adeniyi, M.I., Aberuagba, F. and Adeniyi, O. D. "Production and preservation of fruit juice from African locust bean (parkia biglobosa)", AU Journal Technology, vol.14 (2), 2010, pp 111-118

[13] Koura, K., Ganglo, J. C. Assogbadjo, A. E., and Agbanda, C. "Ethnic differences in use values and use patterns of parkia biglobosa in Northern Benin, Journal of Ethnobiology and Ethnomedicine, vol. 7(42), 2011

[14] Olorunmaiye, K.S. Fatoba, P.O., Adeyemi, O. C. and Olorunmaiye, P.M. "Fruit and seed characteristics among selected parkia biglobosa (JACQ) G.D. on population", Agriculture and Biology Journal of North America, vol.2 (2), 2011, pp 244-249

[15] Orwa, C., Mutua, A., Kindt, R., Jamadass, R. and Simon, A. "Agroforestree data base", a tree reference and selection guide version 4.0, 2009

[16] Ibrahim F. B., Otun, J. A., Adie, D.B. and Jagaba, N.Z. "Removal of some selected heavy metals from tannery wastewater using powdered limestone, Nigerian Journal of Engineering, vol. 18(1), 2011, pp 89-95

[17] Hameed, B. H., Foo, K. Y. "Insight into the modeling of adsorption isotherm systems", Chemical Engineering Journal, vol. 156, 2010, pp 2-10

[18] Sincero, A. P. and Sincero, G. A. "Environmental Engineering", A design approach, Prince - Hall of India, New Delhi, 2006
[19] Verla, A. W., Horstall, M. Verla, E. N., Spiff, A. I. and Ekpete, 0. A. "Preparation and characterization of activated carbon from fluted pumpkin (Telfairaoccidentalis Hook F) seed shell, Asia Journal of Natural and Applied Sciences, vol. 1(3), 2012

[20] Dada, A. O., Olalekan, A. P., Olatunya, A. M., and Dada, O. "Langmuir, Freundlich, Tempkin and DublinRadushkevich, Isotherms of equilibrium soption of Zn (ii) unto phosphoric acid modified rice husk, IOSR Journal of Applied chemistry, vol. 3(1), 2012, pp 38- 45

[21] Kudaybergenov, K. K., Ongarbayev, E. K. and Mansurov, Z. A. "Thermally treated rice husk for petroleum adsorption, International Journal of Biology and Chemistry, vol. 1, 2012, pp 3-12

[22] Adamu, A., Adie, D. B. and Alka, U. A. "A comparative study of the use of cassava species and alum in Wastewater treatment, Nigerian Journal of Technology, vol. 33, 2014, No. 2, pp 170-175

[23] Mohammed, Y. S. "Performance evaluation of rice husk activated carbon in water treatment and removal of phenol", PhD thesis, Department of Water Resources and Environmental Engineering, Ahmadu Bello University Zaria- Nigeria, 2015

[24] Daffalla, S. B., Hilmi, M. and Maizatul,S. S. "Effect of organic and inorganic acid pretreatment on structural properties of rice husk and adsorption mechanism of phenol", International Journal of chemical and Environmental Engineering, vol.3 (3), 2012. 